\title{
Spatial and temporal variation in weather events critical for boreal agriculture: I Elevated temperatures
}

\author{
Pirjo Peltonen-Sainio ${ }^{1}$, Pentti Pirinen², Hanna M. Mäkelä², Otto Hyvärinen², Erja Huusela-Veistola ${ }^{1}$, Hannu Ojanen ${ }^{3}$, Ari \\ Venäläinen² \\ ${ }^{1}$ Natural Resources Institute Finland (Luke), Management and Production of Renewable Resources, FI-31600 Jokioinen, Finland \\ ${ }^{2}$ Finnish Meteorological Institute, PL 503, FI-00560 Helsinki, Finland \\ ${ }^{3}$ Natural Resources Institute Finland (Luke), Green Technology, Fl-31600 Jokioinen, Finland \\ e-mail: pirjo.peltonen-sainio@luke.fi
}

\begin{abstract}
Variation in temperature challenges crop production and animal farming. Elevated temperatures are often harmful, though may also open opportunities at high latitudes. Impacts depend on the vulnerability of the object, production system and their resilience to climatic variability. The station-wise temperature observations from the Finnish Meteorological Institute for a time period of 54 years (1961-2014) were interpolated to a regular $10 \mathrm{~km} \times 10 \mathrm{~km}$ grid covering the whole country. Several successive time slices were used to measure the likelihood for: 1 ) elevated temperatures of a) $\geq 1{ }^{\circ} \mathrm{C}$ above normal for three weeks, b) $\geq 2{ }^{\circ} \mathrm{C}$ above normal for two weeks and c) $\geq 3{ }^{\circ} \mathrm{C}$ above normal for one week, and 2) heatwaves with daily maximum temperature $>25^{\circ} \mathrm{C}$ for: a) 5 days (short) or b) 14 days (long episode). We also estimated the likelihood of warm winds in the early growing season which may enhance pest migration. We found large spatial and temporal variations in the likelihoods of elevated temperatures with many impacts on crop production, animal farming and welfare. In fact, only $1{ }^{\circ} \mathrm{C}$ temperature elevation may already be harmful, though in some cases also beneficial depending on region and vulnerability or adaptation of the object and production system. Though we show only some examples of the potential impacts of temperature variation on high latitude agro-ecosystems, these data are valuable as such for much wider applications in agriculture and beyond that.
\end{abstract}

Key words: animal welfare, crop production, elevated temperature, heatwaves, probability, variability

\section{Introduction}

Finland is in the north temperate region above $60^{\circ} \mathrm{N}$, in Boreal environmental zone (Metzger et al. 2005) with cool growing seasons, cold winters and rains distributed throughout the year (Solantie 1990). Due to its northern location, growing conditions in Finland encase many challenges for agricultural operations related to temperature and its variation (Peltonen-Sainio et al. 2014). At such high latitudes, the agronomically effective part of the growing season is short, as only part of the thermal growing season can be utilized for food, feed and biomass production (Peltonen-Sainio et al. 2009a).

The accumulated temperature sum from sowing to harvest and the within season dynamics vary markedly from one season to another. The typical range from sowing to harvest time is from ca. $800^{\circ} \mathrm{Cd}$ to $1,300^{\circ} \mathrm{Cd}\left(+5^{\circ} \mathrm{C}\right.$ as a base temperature) with higher likelihoods for higher accumulation of degree days in the southern and southwestern coastal regions (Peltonen-Sainio et al. 2009a). Despite the very short growing season, shifts in time of sowing and ripening are common. However, delays in sowing do not necessarily mean corresponding delays in ripening in the case that elevated daily mean temperatures enhance crop development rate (Peltonen-Sainio and Jauhiainen 2014) - and even radically so when heatwaves occur.

A low number of cumulated degree days limits both spring crop and cultivar choices and challenges the aims of diversifying high latitude agricultural systems. Furthermore, crop production is particularly prone to temperature variation, as crop growth and development are strongly controlled by temperature (Peltonen-Sainio and Rajala 2007). Elevated temperature causes yield losses e.g. due to a lower number of yield components such as grains per head (Peltonen-Sainio et al. 2011). It also reduces biomass, increases lignification of forage crops and inhibits regrowth after cutting (Bertrand et al. 2008, Kuoppala 2010). In addition to direct effects on crop growth, elevated temperatures may increase the need for crop protection against pests and diseases (Kurppa 1989, Hakala et al. 2011). Hence, elevated temperatures are recognised as being among the most harmful weather events for high latitude agriculture (Peltonen-Sainio et al. 2016). However, at late grain-filling, elevated temperatures may advance maturation processes and, thereby, favour harvests and reduce costs caused by grain drying. 
It is recognised that high latitude agriculture as it is currently practiced is an outcome of long-term adaptation to high latitude conditions with many specific features such as long days and a high number of climatic handicaps. The climatic conditions as such are not, however, the greatest challenge for agriculture in these northernmost regions of Europe, but the high fluctuation of weather conditions. This study is a trilogy, and each sub-paper concentrates on variation recognised for different types of weather parameter. This first paper aims to characterize the spatial and temporal variation in temperature conditions, which are gridded across Finland for many successive time slices that, as a whole, cover the period prior to the onset of field operations in the spring to those after harvests and sowings in the autumn.

\section{Materials and methods}

All meteorological data except the data used in calculation of warm winds enhancing pest migration were based on weather observations made by the Finnish Meteorological Institute (FMI), where it was quality checked and stored in a climate database. The station-wise weather observations were interpolated to a regular $10 \mathrm{~km} \times 10 \mathrm{~km}$ grid covering the whole country using similar spatial interpolation method as applied by Aalto et al. (2013) for monthly data. The method is routinely applied for all spatial climate analyses in the Finnish Meteorological Institute. The time period studied was 54 years (1961-2014). The reference period (1981-2010) was used to calculate deviations from the mean values.

Elevated temperatures were measured as also described in Peltonen-Sainio et al. (2016). Probabilities (\%) for higher than normal temperatures during the growing season (15 April to 30 September) were estimated using three different criteria: 1) daily mean temperatures that were at least $1{ }^{\circ} \mathrm{C}$ higher than normal temperatures and lasted for three weeks, 2) $2{ }^{\circ} \mathrm{C}$ higher than normal and lasted for two weeks, and 3) $3{ }^{\circ} \mathrm{C}$ higher than normal and lasted for one week. The comparison was done daily wise, i.e. each day's temperature had to be higher than the long term (1981-2010) mean for that day. The highest temperature elevation of $\geq 3{ }^{\circ} \mathrm{C}$ for one week had the highest probabilities. The calculations were made twice a month (on the $15^{\text {th }}$ and the last day of the month). The procedure for estimating probability for $3^{\circ} \mathrm{C}$ higher than normal temperature for one week is shown here by giving an example for mid-August: 1) for each year in 1961-2014 the number of days with higher than normal daily mean temperatures was calculated for the preceding week to August 15. If the actual daily mean temperature was higher than the normal value by $+3{ }^{\circ} \mathrm{C}$, the number of days increased by one; 2 ) the average temperature for the period was calculated; 3 ) if more than six days with higher than normal temperatures was recorded and the average temperature for the period was equal or higher than the normal temperature plus $3^{\circ} \mathrm{C}$, the year was considered to fulfil the condition; and 4) the probability (\%) was expressed according to Eq. [1].

$100 \times[$ number of accepted years / total number of years $(=54)]$

Eq. [1]

Heatwaves were considered to take place when the daily maximum temperature exceeded $25^{\circ} \mathrm{C}$. Two definitions for heatwaves were considered: 1 ) heat lasting at least five consecutive days (short episode), and 2) heat lasting at least 14 days (prolonged heat) with no more than two days having a daily maximum temperature lower than $25.1^{\circ} \mathrm{C}$ during the two week period. The probabilities were calculated from 15 April to 30 September on the $15^{\text {th }}$ and the last day of each month according to Eq. [1].

Warm winds having the potential to enhance pest migration were considered to take place when three conditions were fulfilled: 1) the wind direction was from 90 to 270 degrees, 2) the mean daily temperature was above $0{ }^{\circ} \mathrm{C}$, and 3 ) the daily maximum temperature was $5{ }^{\circ} \mathrm{C}$ above the normal. From the ERA-Interim reanalysis (Dee et al. 2011), values of $2 \mathrm{~m}$ temperature and $10 \mathrm{~m}$ wind were retrieved for years 1979-2009. For each grid point, the number of days when all three conditions were fulfilled for each year was counted for the period from 15 April to 31 May. The negative binomial distribution (NBD) was fitted to the counts. NBD is a mixture of Poisson distributions with the mean distributed as a gamma distribution, parametrized by the mean $\mu$ and the dispersion parameter size. In practice, $\mu$ of NBD and the mean $\lambda$ of the Poisson distribution were identical and size controls the density so that smaller count values were better modelled. 


\section{Results}

A short period lasting for one week with daily mean temperatures exceeding the normal by $3{ }^{\circ} \mathrm{C}$ (Figs. $1 \mathrm{a}$ and $1 \mathrm{~b}$ ) was more common than two weeks period with daily mean temperatures exceeding the normal by $2{ }^{\circ} \mathrm{C}$ (Figs. $2 \mathrm{a}$ and $2 \mathrm{~b}$ ) or three weeks period exceeding the normal by $1{ }^{\circ} \mathrm{C}$ (Figs. 3a and $3 \mathrm{~b}$ ). Highly elevated temperatures lasting for one week were particularly probable in early summer: from the end of May to the end of June. The risk was particularly high at the end of May (Fig. 1a) when the probabilities ranged from 9 to $11 \%$ in the prime field crop production region. In some southern regions, the probability of highly elevated temperatures (by $3^{\circ} \mathrm{C}$ ) was even up to $15 \%$, whereas next to the coast the likelihood was lower (4-8\%) again. The differences between regions were, however, high (e.g. 4-15\% for the end of May), and the probabilities shifted from one region to another depending on the time of the season. Highly elevated temperatures lasting for 7 days were, however, also rather common in late July to early August in some inland and/or eastern parts of the country, whilst they were most likely to occur in mid-July and September in northern parts of the country (Figs. 1a and 1b).
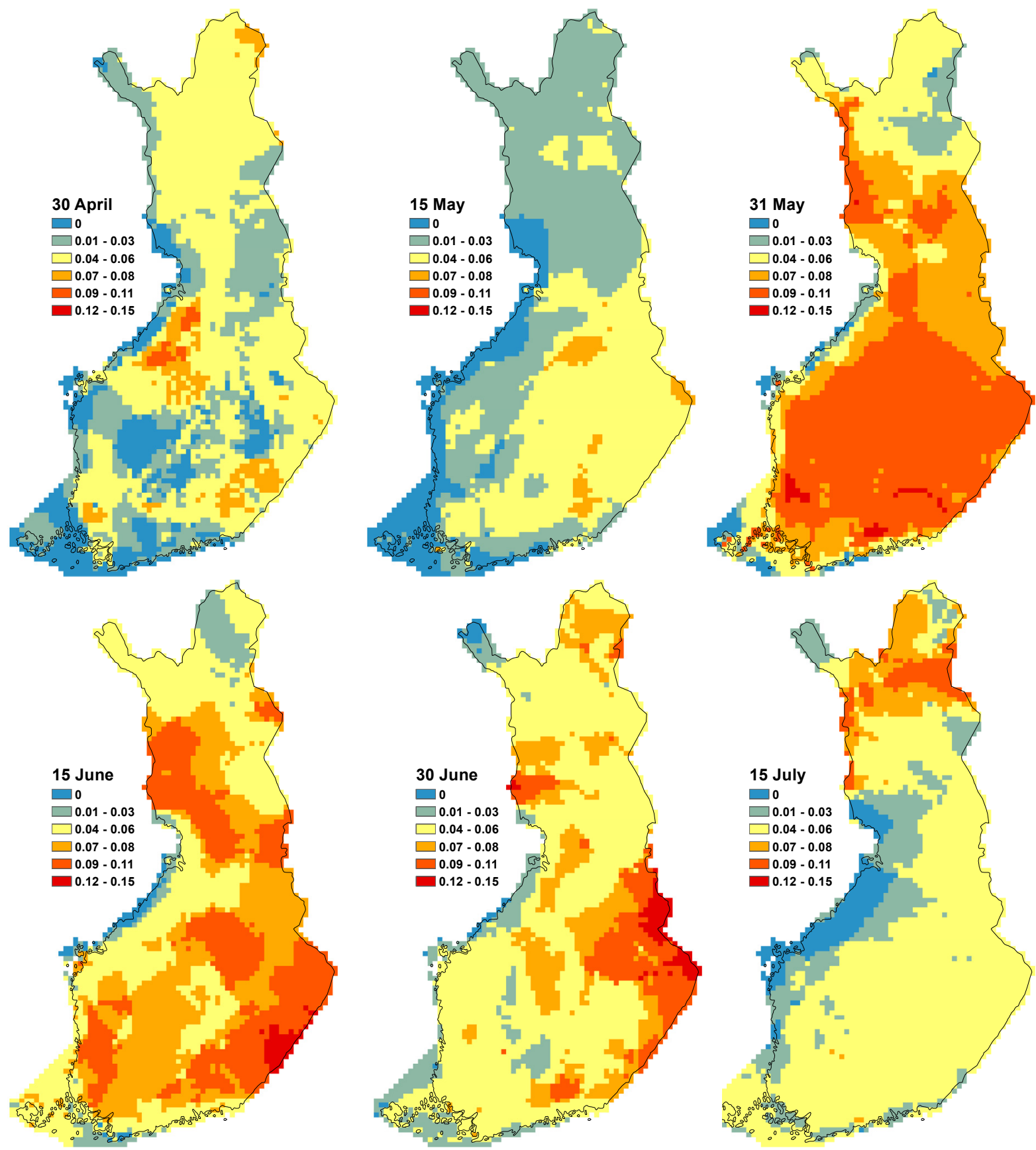

Fig. 1a. Probabilities of elevated temperatures of $\geq 3{ }^{\circ} \mathrm{C}$ that lasted for at least one week for the periods that ended on $30 \mathrm{April}$ to $15 \mathrm{July}$ 

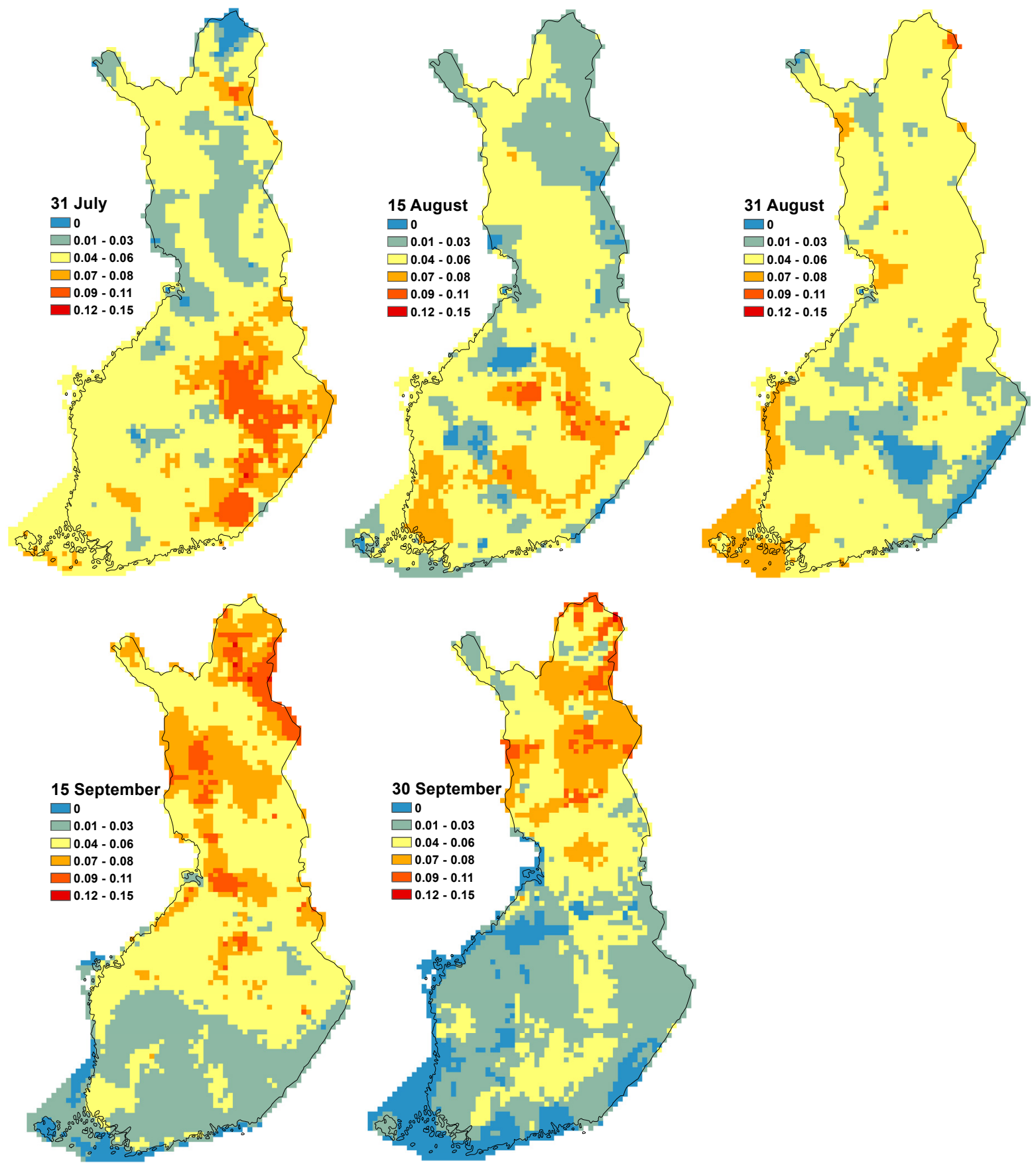

Fig. 1b. Probabilities of elevated temperatures of $\geq 3{ }^{\circ} \mathrm{C}$ that lasted at least for one week for the periods that ended on 31 July to 30 September 
Regional distribution of probabilities of having two weeks of $2{ }^{\circ} \mathrm{C}$ or three weeks of $1{ }^{\circ} \mathrm{C}$ elevation of daily mean temperature differed depending on timing and region (Figs. $2 \mathrm{a}$ to $3 \mathrm{~b}$ ). The probability of having three weeks of $+1{ }^{\circ} \mathrm{C}$ was more likely to occur close to sowing than was a two-week period with $+2{ }^{\circ} \mathrm{C}$. The highest likelihood for coastal regions of three weeks of $+1{ }^{\circ} \mathrm{C}$ was in mid-September by even up to $15 \%$. Elsewhere and at different time periods the likelihoods typically ranged from 1 to $6 \%$ (up to $8 \%$ in mid-June). Virtually, probabilities of two weeks of temperatures elevated by $2{ }^{\circ} \mathrm{C}$ did not exceed $6 \%$ at all, and they were highest during the growing season (Figs. 2a and $2 b$ ).
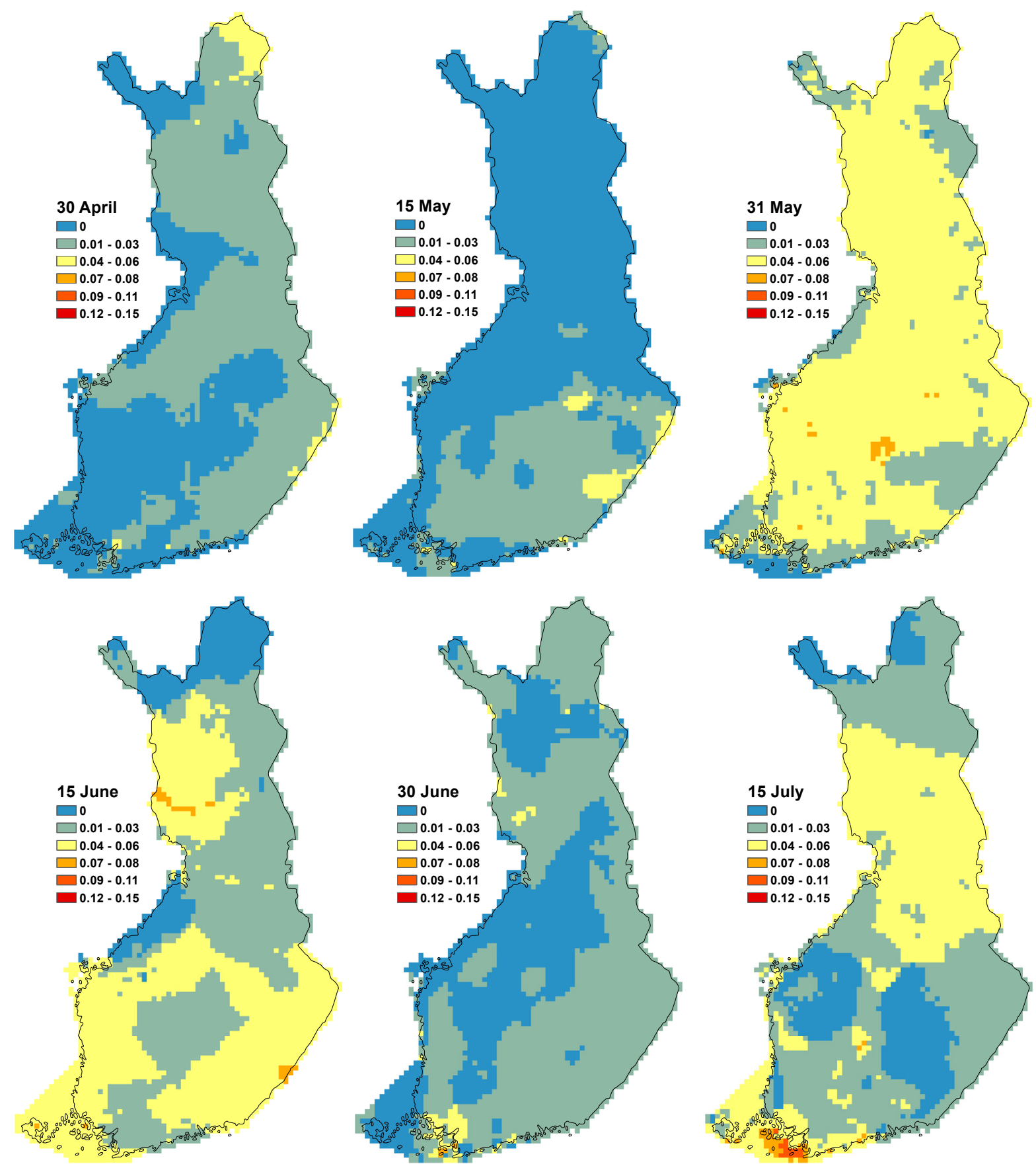

Fig. 2a. Probabilities of elevated temperatures of $\geq 2{ }^{\circ} \mathrm{C}$ that lasted for at least two weeks for the periods that ended on $30 \mathrm{April}$ to $15 \mathrm{July}$ 

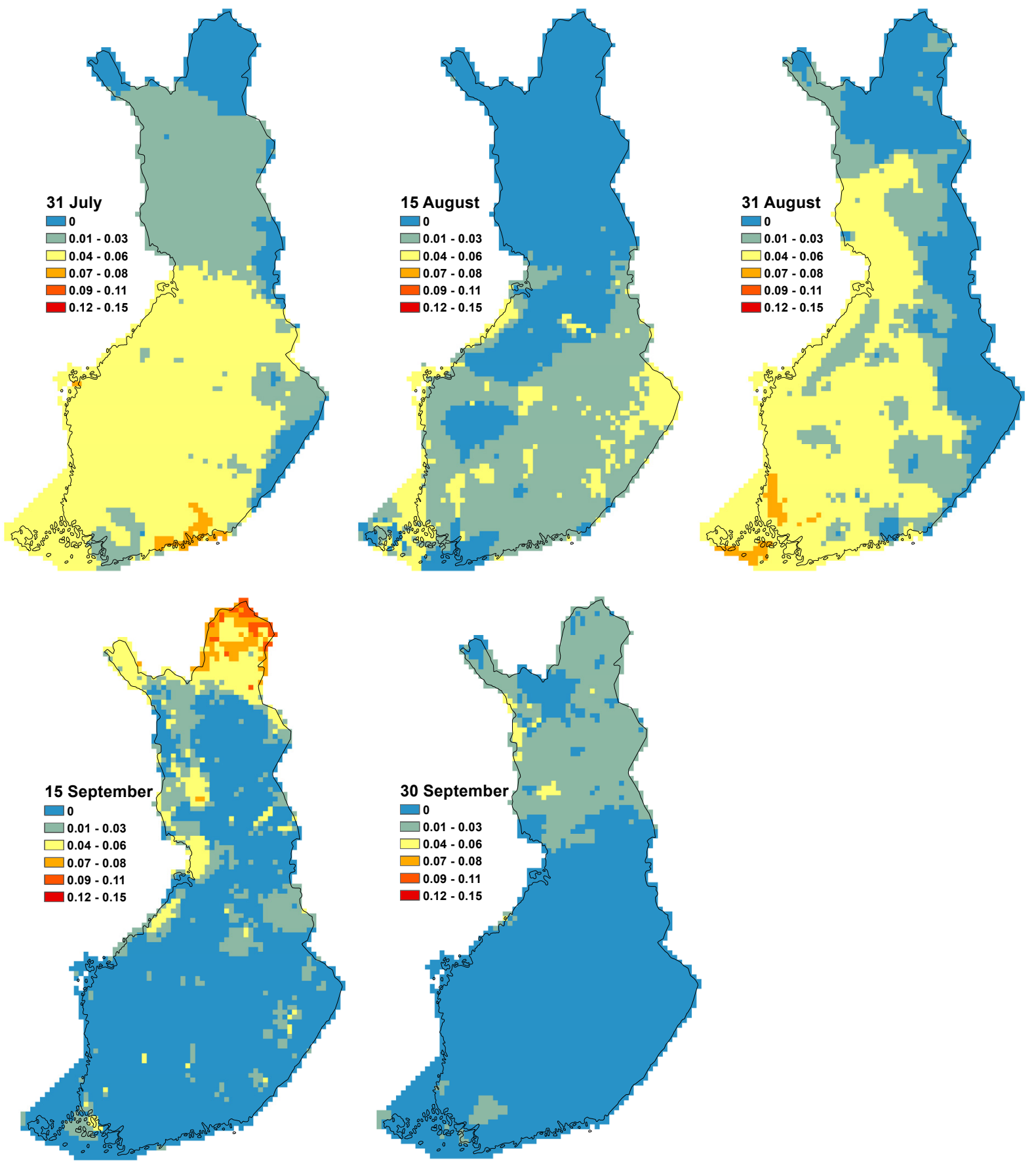

Fig. 2b. Probabilities of elevated temperatures of $\geq 2{ }^{\circ} \mathrm{C}$ that lasted for at least two weeks for the periods that ended on 31 July to 30 September 

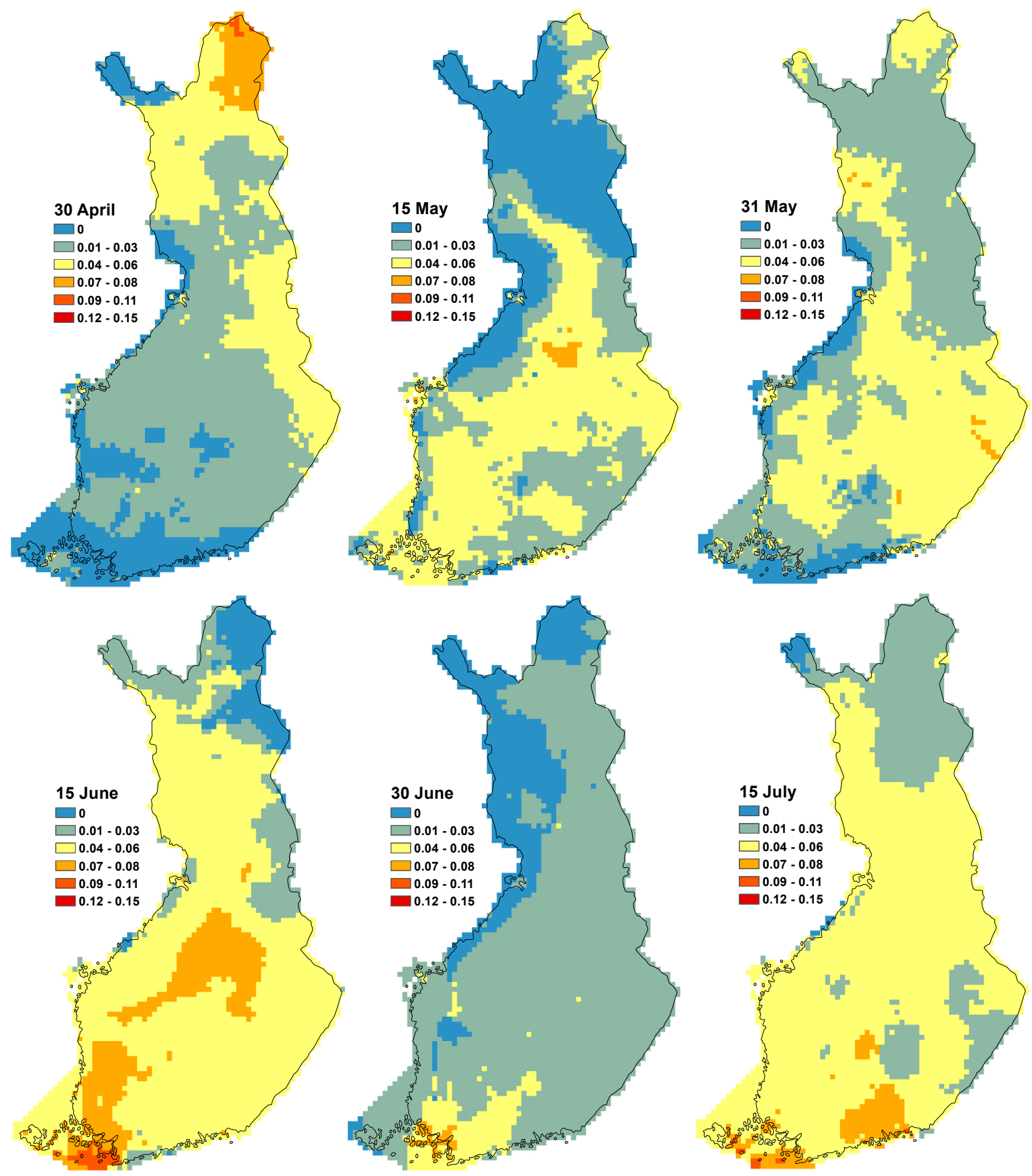

Fig. 3a. Probabilities of elevated temperatures of $\geq 1^{\circ} \mathrm{C}$ that lasted for at least three weeks for the periods that ended on $30 \mathrm{April}$ to $15 \mathrm{July}$. 

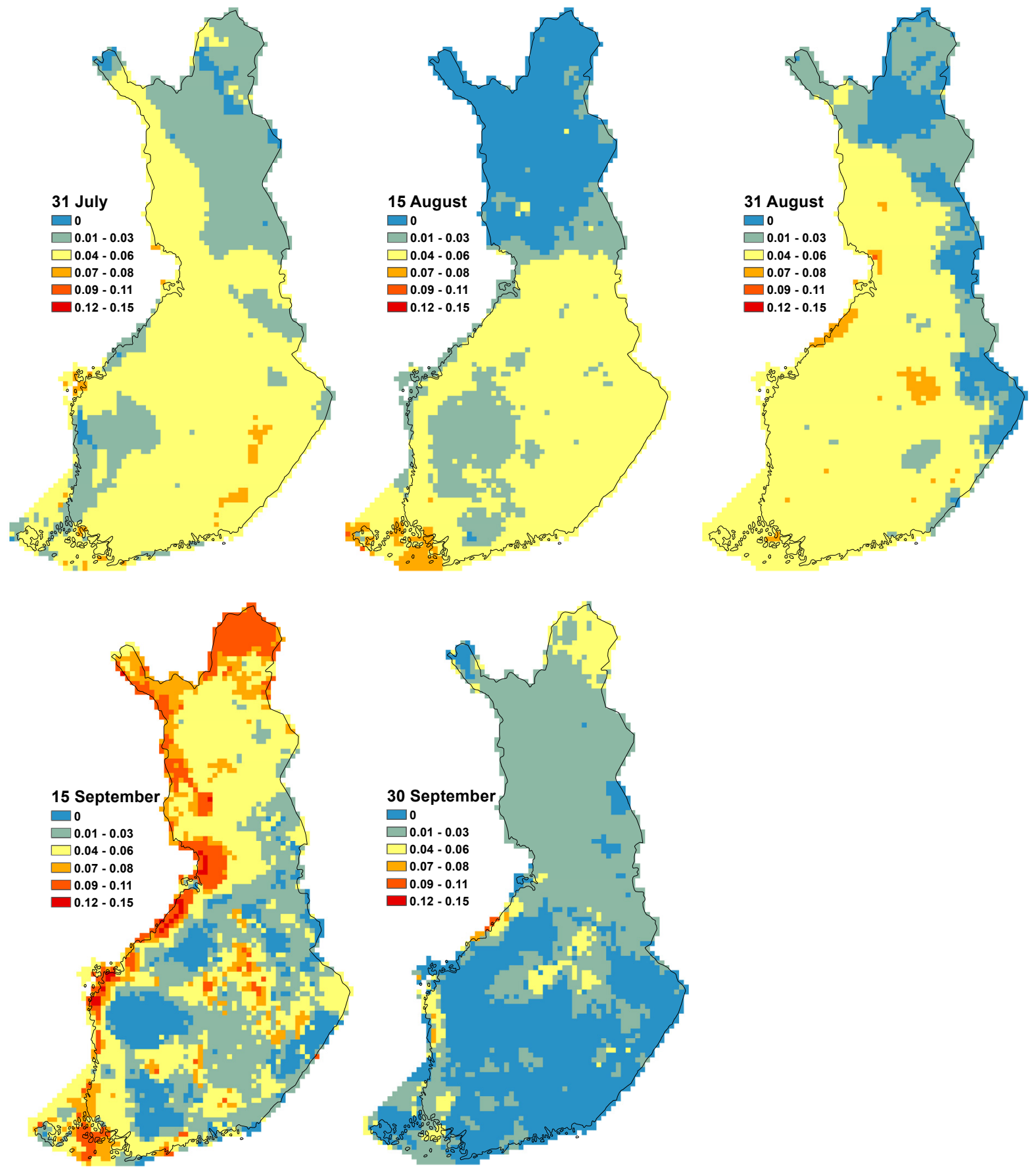

Fig. 3b. Probabilities of elevated temperatures of $\geq 1{ }^{\circ} \mathrm{C}$ that lasted for at least three weeks for the periods that ended on 31 July to 30 September 
Heatwaves with maximum daily temperatures exceeding $25^{\circ} \mathrm{C}$ on at least for five successive days occurred most frequently from mid-June to the end of July (Fig. 4). The likelihood was highest, up to $15 \%$, for south-east coastal and inland regions, and particularly so in July. On the other hand, long-lasting heatwaves (up to 12-14 days) were only recorded for eastern Finland at a $2-5 \%$ likelihood by mid-July and for south-eastern regions with $5-10 \%$ likelihood by the end of July (data not shown).
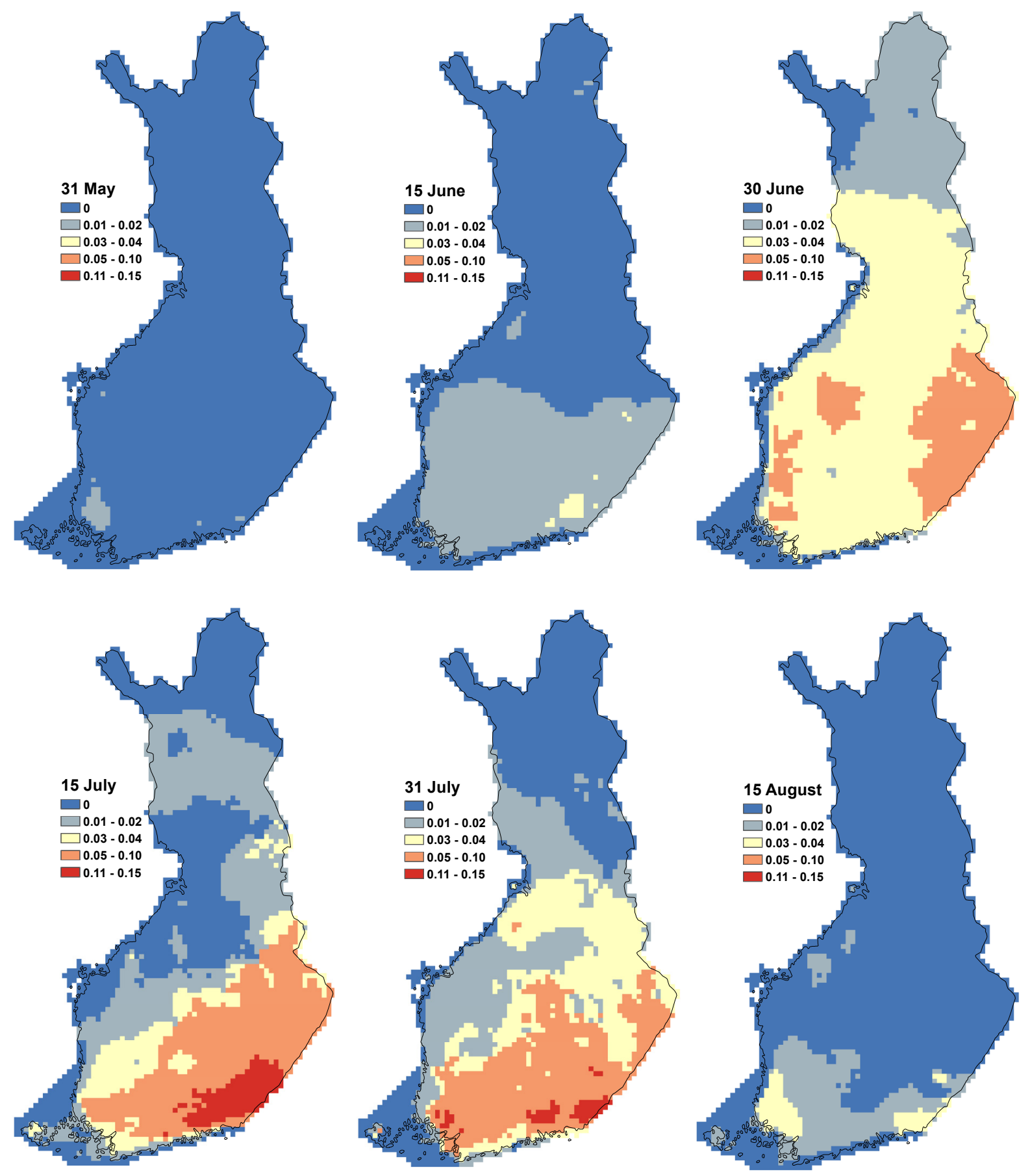

Fig. 4. Probabilities of heatwaves with daily maximum temperatures $>25^{\circ} \mathrm{C}$ that lasted for at least five days (short episode) for the periods that ended on 31 May to 15 August 
Based on the grid wise probability distributions, the probability of enhanced pest migration conditions existing was calculated (Fig. 5a) and then the mean number of days fulfilling the conditions was calculated (Fig. 5b). The conditions were fulfilled more often in southern than in northern Finland. In most of Finland, the probability of at least one day per year was $>50 \%$, but the mean number of days was still less than four in the whole of Finland. Largest values were in east-central Finland and in southern coastal areas of Finland.

a)

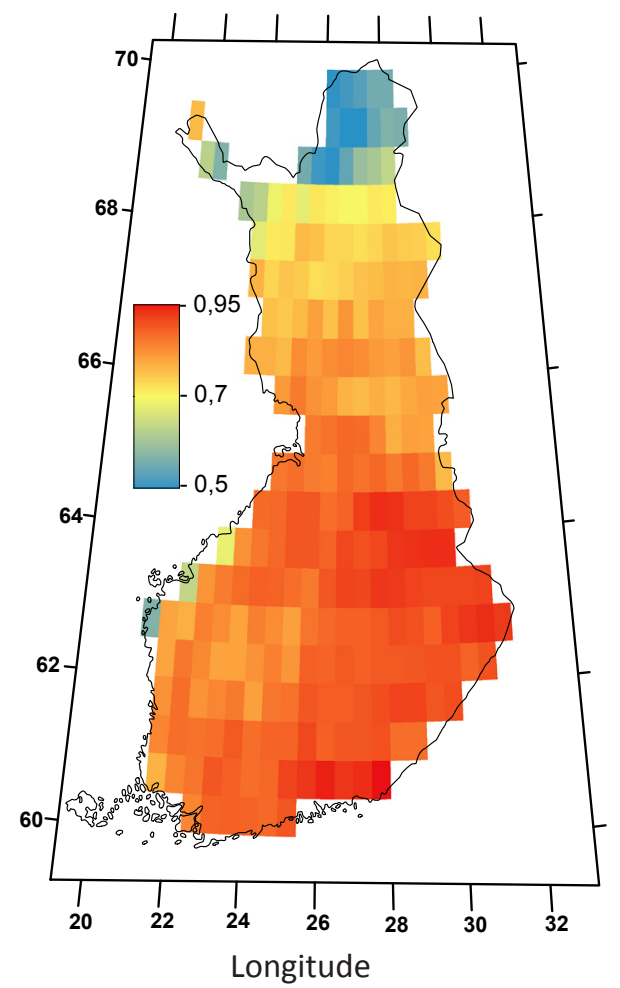

b)

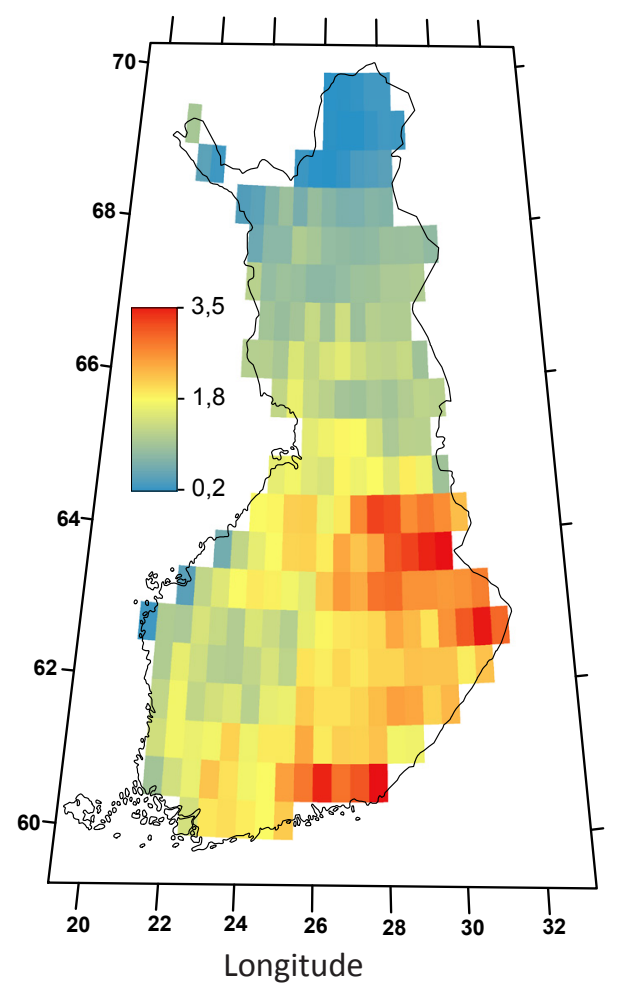

Fig. 5. a) The probability that the number of days fulfilling the conditions for enhanced pest migration is at least one, and b) the mean number of days favouring pest migration

\section{Discussion}

This study highlighted the risks of elevated temperatures for high latitude agriculture according to past data covering 54 years, and it demonstrated high spatial and temporal (within seasonal) differences in the probabilities of elevated temperatures. Variation in temperature has a large number of direct and indirect impacts on agriculture ranging considerably in harmfulness (Peltonen-Sainio et al. 2014, 2016). Here, we show only some examples of impacts of elevated temperatures on the agricultural sector to encourage the many-sided use of the datasets that were produced in on-going project on climatic variability. However, due to climate change, elevated temperatures and extreme heat are likely to become more common in the future (IPCC 2012, 2013). This calls for an adaptation strategy with identified, large scale actions in the agricultural sector, but also beyond that in other sectors (MMM 2014). The datasets shown here might also serve as a retrospect for a variety of future-oriented studies.

In general, cool growing conditions favour yield formation at high latitude conditions (Peltonen-Sainio et al. 2011, Hakala et al. 2012), but again low temperatures exhibit a risk of delayed harvests, quality and yield losses, harvest failures and higher energy costs for seed drying (Peltonen-Sainio et al. 2014). Postponed harvests may also mean that field operations are carried out in conditions that may risk damaging the soil structure (Alakukku et al. 2003). Contrary to this, elevated temperatures advance crop development and often enable harvesting in good conditions, but are likely to cause yield and quality penalties such as reduced grain size in cereals (Mukula and Rantanen 1989a, 1989b, 1989c, Rötter et al. 2011, Peltonen-Sainio and Jauhainen 2014). 
The highly elevated temperatures (by $\geq 3{ }^{\circ} \mathrm{C}$ ) lasting for one week and being particularly detrimental for yield formation (Rötter et al. 2011) were particularly probable in the early growing season. Interestingly, the particularly detrimental short periods with high temperature elevation were more common than longer periods with a more reasonable increase in daily mean temperatures (Figs. $1 a$ to $3 b$ ). The probability was already high by the end of May (9-11\%) when seedlings of spring-sown crops emerge and/or plant stands are established. At that time, autumn sown crops are also close to heading and flowering. This phenomenon was found throughout the prime agricultural region of Finland (Fig. 1a), but with some regional differences in likelihoods for high temperature elevation. It was notable that the risk of a $3{ }^{\circ} \mathrm{C}$ temperature elevation shifted from one region to another along with time (i.e. towards the eastern parts of the country) as do also the sowings and timing of phenophases (Peltonen-Sainio and Jauhiainen 2014). Such parallel shifts make the spring-sown cereals across the country prone to losses caused from elevated temperatures (Peltonen-Sainio et al. 2011, Rötter et al. 2011).

Elevated temperatures may also increase the risk of pest invasion and disease outbreaks, because e.g. the developmental rate and the number of generations of offspring are often higher at elevated temperatures (Bale et al. 2002, Hakala et al. 2011). Warm winds in late spring and/or early summer may also favour the long-range migration of pest species that are not capable of overwintering due to harsh winter conditions. Therefore, their outbreaks result solely from immigration. The probability of warm winds was highest in east-central Finland and in southern coastal areas of Finland (Fig. 5), which agrees in general with the observations on pest migration. For example, in 2013 and 2014 warm winds favoured early summer migration of Plutella xylostella. Outbreaks of P. xylostella and severe damage caused to oilseed crops have occurred especially in warm seasons (e.g. 1995, 2010, 2013 and 2014) when early migrants have arrived as early as in May (Erja Huusela-Veistola, personal communication, 20 March 2015). Long-range migration is important also for outbreaks of Rhopalosiphum padi especially in early spring when local domestic populations are still as the nymph stage in their winter host Prunus padus (Kurppa 1989). The early arrivals in the fields are often correlated with the abundance of aphids and severity of damage because the risk is greatest during the seedling stage of spring cereals. Furthermore, the epidemics of barley yellow dwarf virus (BYDV) have clearly been connected with outbreaks of $R$. padi (Kurppa 1989). Temporal and spatial variation in the abundance and importance of pest insects is typical in arable cropping and the risk of pest migration is highest in southern and eastern Finland. Therefore, a pest immigration warning system based on weather radars and trap monitoring would be an important integrated pest management tool for farmers (Leskinen et al. 2011).

Heatwaves, meaning that the maximum daily temperatures exceeded $25^{\circ} \mathrm{C}$ for at least five successive days, occurred most frequently from mid-June to the end of July. This means again during the most vulnerable yield determination phase and also at the early onset of grain filling of the spring sown grain and seed crops. Winter sown crops are at that time already in the grain filling phase and can hence partly, escape from the yield losses (Peltonen-Sainio et al. 2011). In the dairy regions, heatwaves are most likely experienced around and after the first cut of the forage crops, thereby causing early lignification and reduced regrowth as discussed also in relation to elevated daily mean temperatures. The likelihood was indeed highest, up to $15 \%$, in the south-east coastal and inland regions and particularly so in July (Fig. 4).

Contrary to elevated temperature-induced yield penalties often experienced by the most commonly grown crops, some minor crops such as peas (Pisum sativum L.) (Peltonen-Sainio et al. 2011) and faba beans (Vicia faba L.) (Stoddard et al. 2009) may even favour warm growing conditions. Also, cultivation of higher yielding and more robust oilseed rape (Brassica napus L.) is encouraged (and anticipated to replace turnip rape, B. rapa L.) in the regions with a higher likelihood of higher cumulated degree days during the growing season (Peltonen-Sainio et al. 2009a). These are all crops that are envisaged as being among the first crops having a higher potential to be grown as major and not only minor crops in Finland due to climate change (Peltonen-Sainio et al. 2009b, 2009c, 2013a). Currently, the cultivation areas of these crops fluctuate greatly from one year to another as they are considered to suffer from unstable yields mainly caused by climatic variation (Peltonen-Sainio et al. 2013a). However, they may gradually become ossified when farmers have encouraging experience during warm summers. Actually, our recent paper supports this, as farmers readily benefit from later maturing cultivars and late maturing wheat instead of early maturing barley after warm growing seasons (Peltonen-Sainio et al. 2013b). Furthermore, after becoming familiar with the warm summers of the 2000s, farmers have recently been keen on testing forage maize (Zea mays L.) even up to $64^{\circ} \mathrm{N}$. Though not yet showing any promise of expansion beyond test sites in Finland (Elsgaard et al. 2012), farmers gradually become familiar with this novel crop, which may support proactive adaptation to climate change. 
As referred to above, the likelihood of temperature elevation differs depending on time and region. The risk of elevated temperature stress and/or heatwaves coincided with the critical growth phases of forage crops in their northern and eastern production regions. This may impair regrowth after cutting and thereby reduce the number of cuts, enhance lignification processes and, in general, cause great variation in quality, nutritive value and digestibility of pasture, hay and/or silage (Bertrand et al. 2008, Kuoppala 2010). Thereby, quality and yield losses of forage crops induced by temperature variation may have a major economic impact on animal farms, but may also reflect on animal welfare in many ways - also through direct and indirect health risks (Gauly et al. 2013).

The likelihood of actual heatwaves was low (0-4\%) for the Finnish Arctic as one might expect (Fig. 4), but temperatures that elevated above the mean were more common (up to a 15\% probability) and occurred in early September in Lapland. The probabilities of temperature shifts were then comparable to or even exceeded those observed elsewhere (Figs 1b, 2b and 3b). These regions are not, however, agronomically important, but elevated temperatures may influence Arctic reindeer (Rangifer tarandus) e.g. by changes in vegetation, its biomass and quality, the degree of insect harassment and associated parasitism (Weladji et al. 2003, Weladji and Holand 2006, Dobson et al. 2015).

\section{Conclusions}

We found large spatial and temporal variation in the likelihood of elevated temperatures according to the long-term climatic data of the Finnish Meteorological Institute. Such variations in temperature conditions per se have many proven impacts on not only crop production, but also animal farming and animal welfare. Furthermore, a temperature elevation of only $1{ }^{\circ} \mathrm{C}$ may already have many harmful or, contrary to that, beneficial impacts depending on region and vulnerability and/or adaptation of the organism (such as crops, weeds, animals, pathogens, and pests and their predators). Though, we only "scratch the surface" with our examples on the potential impacts of elevated temperatures, the spatial and temporal data of a $10 \times 10$ grid on temperature variation introduced here are valuable as such for much wider use in agriculture and even beyond.

\section{Acknowledgements}

The work was financed by the Ministry of Agriculture and Forestry and Natural Resources Institute Finland (Luke) as a part of a consortium project entitled Improving Resilience to Climate Change and Variation Induced Risks in Agriculture (ILMAPUSKURI).

\section{References}

Aalto, J., Pirinen, P., Heikkinen, J. \& Venäläinen, A. 2013. Spatial interpolation of monthly climate data for Finland: comparing the performance of kriging and generalized additive models. Theoretical \& Applied Climatology 112: 99-111.

Alakukku, L., Weisskopf, P., Chamen, W.C.T., Tijink, F.G.J., van der Linden, J.P., Pires, S., Sommer, C. \& Spoor, G. 2003. Prevention strategies for field traffic-induced subsoil compaction: a review. Part 1. Machine/soil interactions. Soil \& Tillage Research 73: 145-160.

Bale, J.S., Masters, G.J., Hodkinson, I.D., Awmack, C., Bezemer, T.M., Brown, V.K., Butterfield, J., Buse, A., Coulson, J.C, Farrar, J., Good, J.E.G., Harrington, R., Hareley, S., Jones, T.H., Lindroth, R.L., Press, M.C., Symrnioudis, I., Watt, A.D. \& Whittaker, J.B. 2002. Herbivory in global climate change research: direct effects of rising temperature on insect herbivores. Global Change Biology 8: 1-16.

Bertrand, A., Tremblay, G.F., Pelletier, S., Castonguay, Y. \& Bélanger, G. 2008. Yield and nutritive value of timothy as affected by temperature, photoperiod and time of harvest. Grass and Forage Science 63: 421-432.

Dee, D. P., Uppala, S. M., Simmons, A. J., Berrisford, P., Poli, P., Kobayashi, S., Andrae, U., Balmaseda, M. A., Balsamo, G., Bauer, P., Bechtold, P., Beljaars, A. C. M., van de Berg, L., Bidlot, J., Bormann, N., Delsol, C., Dragani, R., Fuentes, M., Geer, A. J., Haimberger, L., Healy, S. B., Hersbach, H., Hólm, E. V., Isaksen, L., Kållberg, P., Köhler, M., Matricardi, M., McNally, A. P., Monge-Sanz, B. M., Morcrette, J.-J., Park, B.-K., Peubey, C., de Rosnay, P., Tavolato, C., Thépaut, J.-N. \& Vitart, F. 2011. The ERA-Interim reanalysis: configuration and performance of the data assimilation system. Quarterly Journal of the Royal Meteorological Society 137: 553-597.

Dobson, A., Molnár, P.K. \& Kutz, S. 2015. Climate change and Arctic parasites. Trends in Parasitology 31: 181-188.

Elsgaard, I., Børgesen, C.D., Olesen, J.E., Siebert, S., Ewert, F., Peltonen-Sainio, P., Rötter, R. \& Skjelvåg, A. 2012. Shifts in comparative advantages for maize, oat and wheat cropping under climate change in Europe. Food Additives and Contaminants, Part A 29: $1514-1526$.

Gauly, M., Bollwein, H., Breves, G., Brügemann, K., Dänicke, S., Das, G., Demeler, J., Hansen, H., Isselstein, J., König, S., Lohölter, M., Martinsohn, M., Meyer, U., Potthoff, M., Stinshoff, H. \& Wrenzycki, C. 2013. Future consequences and challenges for dairy cow production systems arising from climate change in Central Europe - a review. Animal 7: 843-859.

Hakala, K., Hannukkala, A., Huusela-Veistola, E., Jalli, M. \& Peltonen-Sainio, P. 2011. Pests and diseases in a changing climate: a major challenge for Finnish crop production. Agricultural and Food Science 20: 3-14. 
Hakala, K., Jauhiainen, L., Himanen, S., Rötter, R., Salo, T. \& Kahiluoto, H. 2012. Sensitivity of barley varieties to weather in Finland. Journal of Agricultural Science 150: 145-160.

IPCC 2012. Summary for Policymakers. In: Field, C.B., Barros, W., Stocker, T.F., Qin, D., Dokken, D.J., Ebi, K.L., Mastrandrea, M.D., Mach, K.J., Plattner, G.-K., Allen, S.K., Tignor, M. \& Midgley, P.M., (eds). Managing the Risks of Extreme Events and Disasters to Advance Climate Change Adaptation. A Special Report of Working Groups I and II of the Intergovernmental Panel on Climate Change, Cambridge, Cambridge University Press. 19 p.

IPCC 2013. Summary for Policymakers. In: Stocker T.F, Oin D., Plattner G.-K., Tignor M, Allen S.K., Boschung J, Nauels A., Xia Y, Bex V. \& Midgley P.M. (eds). Climate Change 2013: The Physical Science Basis. Contribution of Working Group I to the Fifth Assessment Report of the Intergovernmental Panel on Climate Change, Cambridge, Cambridge University Press. 28 p.

Kuoppala, K. 2010. Influence of harvesting strategy on nutrient supply and production of dairy cows consuming diets based on grass and red clover silage. http://jukuri.mtt.fi/handle/10024/438301. Accessed 3 April 2015.

Kurppa, S. 1989. Predicting outbreaks of Rhopalosiphum padi in Finland. Annals Agriculturae Fenniae 28: 333-347.

Leskinen, M., Markkula, I., Koistinen, J., Pylkkö, P., Ooperi, S., Siljamo, P., Ojanen, H., Raiskio, S. \& Tiilikkala, K. 2011. Pest insect immigration warning system by an atmospheric dispersion model, weather radars and traps. Journal of Applied Entomology 135: 55-67.

Metzger, M.J., Bunce, R.G.H., Jongman, R.H.G., Mücher, C.A. \& Watkins, J.W. 2005. A climatic stratification of Europe. Global Ecology and Biogeography 14: 549-563.

MMM 2014. Kansallinen ilmastonmuutokseen sopeutumissuunnitelma 2022. Maa- ja metsätalousministeriö 2014. 39 p. (In Finnish).

Mukula, J. \& Rantanen, O. 1989a. Climatic risks to the yield and quality of field crops in Finland. V. Spring wheat 1969-1986. Annals Agriculturae Fenniae 28: 21-28.

Mukula, J. \& Rantanen, O. 1989b. Climatic risks to the yield and quality of field crops in Finland. VI. Barley 1969-1986. Annals Agriculturae Fenniae 28: 29-36.

Mukula, J. \& Rantanen, O. 1989c. Climatic risks to the yield and quality of field crops in Finland. VII. Oats 1969-1986. Annals Agriculturae Fenniae 28: 37-43.

Peltonen-Sainio, P., Hakala, K., Jauhiainen, L. \& Ruosteenoja, K. 2009b. Comparing regional risks in producing turnip rape and oilseed rape - Impacts of climate change and breeding. Acta Agriculturae Scandinavica, B Soil and Plant Science 59: 129-138.

Peltonen-Sainio, P., Hannukkala, A., Huusela-Veistola, E., Voutila, L., Valaja, J., Niemi, J., Jauhiainen, L. \& Hakala, K. 2013a. Potential and realities of enhancing rapeseed- and grain legume-based protein production in a northern climate. Journal of Agricultural Science 151: 303-321.

Peltonen-Sainio, P. \& Jauhiainen, L. 2014. Lessons from the past in weather variability: sowing to ripening dynamics and yield penalties for northern agriculture in 1970-2012. Regional Environmental Change 14: 1505-1516.

Peltonen-Sainio, P., Jauhiainen, L., Hakala, K. \& Ojanen, H. 2009c. Climate change and prolongation of growing season: changes in regional potential for field crop production in Finland. Agricultural and Food Science 18: 171-190.

Peltonen-Sainio, P., Jauhiainen, L. \& Hakala, K. 2011. Crop responses to temperature and precipitation according to long-term multi-location trials at high-latitude conditions. Journal of Agricultural Science 149: 49-62.

Peltonen-Sainio, P., Jauhiainen, L., Niemi, J.K., Hakala, K. \& Sipiläinen, T. 2013b. Do farmers rapidly adapt to past growing conditions by sowing different proportions of early and late maturing cereals and cultivars? Agricultural and Food Science 22: 331-341.

Peltonen-Sainio, P., Jauhiainen, L. \& Venäläinen, A. 2009a. Comparing regional risks in producing turnip rape and oilseed rape Today in light of long-term datasets. Acta Agriculturae Scandinavica, B Soil and Plant Science 59: 118-128.

Peltonen-Sainio, P. \& Rajala, A. 2007. Duration of vegetative and generative development phases in oat cultivars released since 1921. Field Crops Research 101: 72-79.

Peltonen-Sainio, P., Rajala, A., Känkänen, H. \& Hakala, K. 2014. Improving farming systems in northern European conditions. In: Sadras V.O., Calderini D. (eds). Crop Physiology: Applications for Genetic Improvement and Agronomy, updated edition. Amsterdam, The Netherlands: Elsevier. p. 65-91.

Peltonen-Sainio, P., Venäläinen, A., Mäkelä, H.M., Pirinen, P., Laapas, M., Jauhiainen, L., Kaseva, J., Ojanen, H., Korhonen, P., Huusela-Veistola, E., Jalli, M., Hakala, K., Kaukoranta, T. \& Virkajärvi, P. 2016. Harmfulness of weather events and adaptive capacity of farmers at high latitudes of Europe. Climate Research 67: 221-240. DOI: 10.3354/cr01378.

Rötter, R.P., Palosuo, T., Pirttioja, N.K., Dubrovsky, M., Salo, T., Ristolainen, A., Fronzek, S., Aikasalo, R., Trnka, M. \& Carter, T.R. 2011. What would happen to barley production in Finland if global warming exceeded $4{ }^{\circ} \mathrm{C}$ ? A model-based assessment. European Journal of Agronomy 35: 205-214.

Solantie, R. 1990. The climate of Finland in relation to its hydrology, ecology and culture. Finnish Meteorological Contributions 2. $130 \mathrm{p}$.

Stoddard, F., Hovinen, S., Kontturi, M., Lindström, K., \& Nykänen, A. 2009. Legumes in Finnish Agriculture: history, present status and future prospects. Agricultural and Food Science 18: 191-205.

Weladji, R.B. \& Holand, $\varnothing$. 2006. Influences of large-scale climatic variability on reindeer population dynamics: implications for reindeer husbandry in Norway. Climate Research 32: 119-127.

Weladji, R.B., Holand, $\varnothing . \&$ Almøy, T. 2003. Use of climatic data to assess the effect of insect harassment on the autumn weight of reindeer (Rangifer tarandus) calves. Journal of Zoology 260: 79-85. 